\title{
Characterisation of Microplastics from the Effluent of a Municipal Wastewater Treatment Plant and from its Natural Receptor
}

\section{GHEORGHE BATRINESCU ${ }^{1 \#, ~ I O A N A ~-~ A L E X A N D R A ~ I O N E S C U ~}{ }^{1 \#, ~}$ ROXANA - ELENA SCUTARIU ${ }^{*}$, BOGDAN CHIRICUTA ${ }^{2}$, IONUT CRISTIAN SURUPACEANU ${ }^{2}$}

${ }^{1}$ National Research and Development Institute for Industrial Ecology-ECOIND, Department of Environmental Technologie \&Technological Transfer, 57-73 Drumul Podu Dambovitei, 060652, Bucharest, Romania

${ }^{2}$ Apel Laser SRL, 15 Vintila Mihailescu Str., 060394, Bucharest, Romania

\begin{abstract}
Results obtained from the characterization of three water samples (one representing the effluent of a municipal treatment plant and the two others representing surface water from the Jiu River/Romania, upstream and downstream of the effluent discharge point) are presented in this study in terms of microplastic content. The water samples were processed by successively passing them through a series of filters with the following dimensions: $5 \mathrm{~mm}, 0.5 \mathrm{~mm}(500 \mu \mathrm{m}), 0.1 \mathrm{~mm}(100 \mu \mathrm{m})$ and then through some microfiltration membranes (MF) type EZ-Pak Membrane Filters (Merk-Millipore) made of a mixture of cellulose esters, with an average pore diameter of $0.45 \mu \mathrm{m}$. In order to highlight the microplastics in the water samples, their analysis was performed as well as the solid material retained on the microfiltration membranes, by scanning electron microscopy (SEM) using a SEM Quanta FEG 250/Thermo Fischer Scientific. The results obtained highlighted the existence of microplastics in all the analyzed samples, in the known forms presented in the specialized literature: irregular planes, fibers and spheres. Their dimensions are variable, ranging between $3.2 \mu \mathrm{m}$ and $119.5 \mu \mathrm{m}$ for irregular plane microplastics and between $3 \mu \mathrm{m}$ and $15 \mu \mathrm{m}$ for spherical microplastics. The dimensions of microplastics in the form of fibers are also in the range of tens of $\mu m$ and cannot be established exactly because in most cases they appear in the form of conglomerates. The treatment plant's microplastic effluents content led to the modification of the physical-chemical indicators of the water in their natural receptor. Thus, the content of organic matter and total suspended matter in the downstream water compared to the effluent discharge point is higher than in the upstream water. The analysis of microplastics by SEM allows only their highlighting and their geometry, being a first step in the study of the pollution induced by such materials.
\end{abstract}

Keywords: microplastics, waste waters, wastewater treatment plant, natural receptors

\section{Introduction}

Large scale use of microplastics by people began as lately as the 1950s. Plastics materials found their applicability in various fields, so plastics production has constantly grown ever since. For example, in 2016 the production of plastics worldwide reached a value of 335 million tons, with a $10.4 \%$ increase from the previous year's production of 322 million tons [1]. Between 1950 and 2017, the cumulative production of plastics was estimated at 8300 million tons, of which by 2015, 6300 million tons became waste [2]. Only $9 \%$ of these plastics were recycled, while $12 \%$ were destroyed by incineration. The remaining 79\% were disposed of in municipal landfills. Currently, there is high interest in plastic waste recycling growth, including the recovery of inseparable mixtures of plastics and paper in the form of innovative materials [3]. However, the impact of plastic waste on all environmental components is major. The pollution created by such waste is primarily the consequence of the fact that the lifespan or degradation of plastics is very long. The degradation time ranges from 20 years (polyethylene terephthalate -PET, polyester - PES, polyamide - PA) to over 100 years (polypropylene - PP) or even 
over 140 years in the case of polyvinylchloride - PVC and polytetrafluoroethylene - PTFE [4]. Time degradation processes of plastics under the influence of ultraviolet rays, mechanical processes (friction) or aerobic and anaerobic processes with the help of microorganisms [5], have the effect of crushing them to particles with micron and submicron dimensions. Starting with the year 2002, the first reports on the impact induced by these plastic residues appeared, especially on the marine environment [6]. The notion of "microplastics" (MPs) is then introduced in literature, and did not have an unanimously accepted definition from the beginning. Currently this notion refers to all plastic fragments with dimensions smaller than $5 \mathrm{~mm}$. The appearance of these particles in all environmental components (soil, water, air) has led to an increase in concerns regarding the highlighting of the pollution induced by MPs, scientists, decision makers at various levels being engaged, (local, regional, national, international) and also the general public. Following these concerns, in the first stage, the MPs types and geometric shapes were identified. Thus, MPs from most of the currently used polymers were identified in the environmental factors mentioned above, in one of the following 3 forms: microspheres, microfibers and microfragments with irregular geometry. A large part of the MPs come from large plastic products (plastic bottles, fishing nets, packaging, bags) that decompose into smaller materials, both in the surface waters in which they were discharged and also during the process of storage on municipal landfills. Therefore, the major problems regarding the storage of waste with plastic content on municipal waste landfills are: a) the correct establishment of the waste code (to identify the type of landfill); b) the prediction of the ecological risk induced during the storage of these wastes. Both problems can be addressed by procedures generally valid for most types of waste [7-8]. In the case of non-compliant municipal landfills, MPs generated over time can migrate by leachate into the groundwater and from there into the surface water in the vicinity of the landfill. The presence of MPs on this route can be achieved through methodologies applicable to large categories of pollutants [9]. Other microplastics are introduced into the environment from the beginning with small dimensions. This is the case of microspheres present in personal care products that have exfoliating substances added - creams, shower gels, toothpaste. The microfiber fragments come from the household washing activities made on textile materials such as polyesters and polyamides. All mentioned MPs end up in the surface waters of natural receptors (rivers, lakes, seas, oceans) from the municipal wastewater discharged into them after treatment [10-12]. Identification and quantification of the MPs existing in the aqueous media (in wastewater and surface water in which they are discharged after treatment) is performed by various methods, the most used being scanning electron microscopy with energy-dispersive spectroscopy (SEM-EDS) [13], RAMAN and FTIR-ATR spectroscopy [14]. To highlight the pollution induced by the MPs presence in the flowing water, the quality of water from springs to their discharge point must be analysed using a monitoring system similar to that used to highlight the pollution induced by other pollutants [15-16]. For this purpose, large volumes of water will be taken which will then be processed by laborious methods until obtaining samples with relevant concentrations of MPs that allow their highlighting by the listed methods [17].

The article contains original results obtained in the research process of the separation of MPs from wastewater samples (effluent) from the treatment plant of Targu Jiu/Romania and surface water samples from its natural receptor (Jiu River/Romania), upstream and downstream from the wastewater discharge point. The aspects included in the article refer to the types of MPs identified in the samples analysed by scanning electron microscopy - SEM.

\section{Materials and methods}

Wastewater samples discharged from the treatment plant of Targu Jiu (effluent) and its natural receptor (Jiu River), upstream and downstream were used in the experiments. The sampling points were established so that the samples were relevant to establishing the microplastic matrices from the 3 correlated aqueous media. Their coding and the coordinates of the sampling points are: 
P1 - water discharged from Targu-Jiu municipal treatment plant (effluent): $44^{\circ} 0{ }^{\prime} 47.64 " \mathrm{~N}$, $23^{\circ} 16^{\prime} 8.04^{\prime \prime} \mathrm{E}$;

P2 - surface water (Jiu river) upstream of the treatment plant: $44^{\circ} 59^{\prime} 51.77^{\prime \prime} \mathrm{N}, 23^{\circ} 14^{\prime} 45.09^{\prime \prime} \mathrm{E}$;

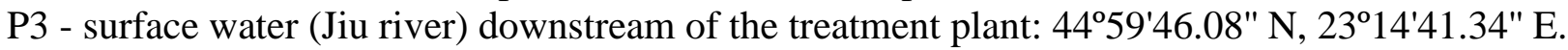

The water samples (40 liters each) were processed by successively passing through a series of filters with the following dimensions: $5 \mathrm{~mm}, 0.5 \mathrm{~mm}(500 \mu \mathrm{m}), 0.1 \mathrm{~mm}(100 \mu \mathrm{m})$. After visual inspection, no microplastics were detected to fit the dimensions listed above. The experiments continued with the filtration of water from each sample through the microfiltration membranes (MF). The microfiltration operation was performed with the help of a vacuum Millipore installation, using EZ-Pak Membrane Filters (Merk-Millipore) type membranes made of a mixture of cellulose esters with a $47 \mathrm{~mm}$ diameter and an average pore diameter of $0.45 \mu \mathrm{m}$.

To highlight the microplastics in the water samples taken (P1-P3), their analysis was performed as well as the solid material retained on the microfiltration membranes, by scanning electron microscopy (SEM) using the SEM Quanta FEG 250 equipment, Thermo Fischer Scientific. These were coded as follows:

P4 - Membrane after microfiltration of the effluent from the treatment plant (P1);

P5 - Membrane after microfiltration of the water sample taken from the receptor upstream of the wastewater discharge point (P2);

P6 - Membrane after microfiltration of the sample water taken from the receptor downstream of the wastewater discharge point (P3).

At the same time, the water from samples P1-P3 was characterized from a physical-chemical point of view, by determining the indicators $\mathrm{pH}$, chemical oxygen demand (COD) and total suspended solids (TSS). The analyzes were performed according to standardized methods. Thus, the value of the $p \mathrm{H}$ indicator was determined according to the method described in SR EN ISO 10523:2012, using a $p \mathrm{H}-$ meter CONSORT C932. For the COD indicator the method described in SR ISO 6060:1996 was used, and for the TSS indicator the SR EN 872:2005 method was used. The interpretation of the values obtained for the mentioned indicators was made in reference to the limit values imposed by the Technical Norm NTPA-001/2005 regarding the establishment of the loading limits with pollutants of industrial and urban wastewater at the discharge in natural receptors.

\section{Results and discussions}

Figure 1 shows images of the microfiltration membranes with solid material (including microplastics) retained on their surface.

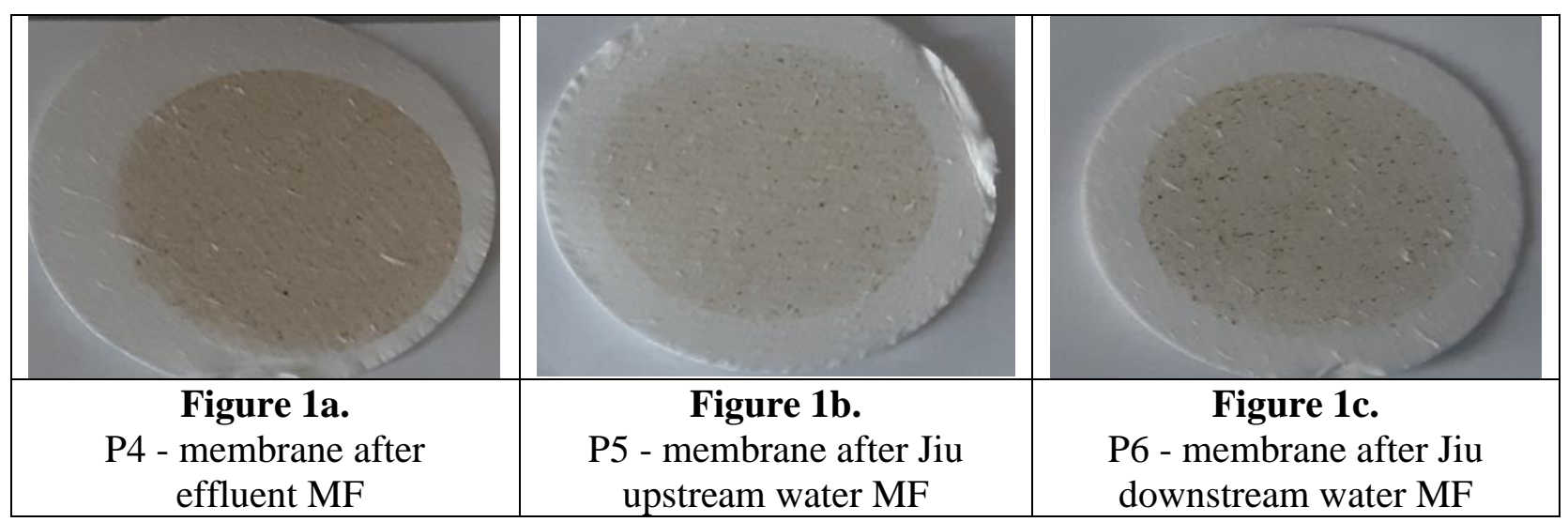


The visual analysis of these images highlights the fact that the effluent from the municipal treatment plant (Figure 1a) has a higher load of solid materials (including microplastics) than the waters of the natural receptor (Jiu River), both upstream (Figure 1b) as well as downstream (Figure 1c). At the same time, it can be seen from comparing the images Figure $1 \mathrm{~b}$ and Figure 1c, the additional loading of the water from the natural downstream receptor with solid materials, brought together with the discharge of the effluent of the treatment plant in it. The mentioned findings are also confirmed by the results of the physical-chemical analyzes presented in Table 1.

Table 1. Results of the physical-chemical analyzes of waters from the samples P1-P3

\begin{tabular}{|c|c|c|c|c|c|}
\hline Indicator & Measurement unit & P1 & P2 & P3 & Limit values \\
\hline $\mathrm{pH}$ & $p \mathrm{H}$ unit & 7.08 & 7.13 & 7.12 & $6.5-8.5$ \\
\hline $\mathrm{COD}$ & $\mathrm{mgO} / \mathrm{L}$ & 26.4 & 17.6 & 20.3 & 125 \\
\hline $\mathrm{TSS}$ & $\mathrm{mg} / \mathrm{L}$ & 10 & 4.8 & 7.2 & 35 \\
\hline
\end{tabular}

The results presented in Table 1 show that the effluent leads to a change in the values of the water indicators in the natural downstream receptor compared to those recorded upstream ( $\mathrm{P} 2$ compared to P3). The changes are a consequence of the higher loading of the effluent water into the organic matter and suspended solids from upstream river water. Even if all the determined values are below the limit values imposed by NTPA-001/2005, it is found that the effluents of the treatment plants bring additional pollutants in natural receptors, including microplastics which represent a fraction of the suspended solids.

In Figures 2 to 4 the results obtained from the SEM analysis of the initial samples (P1-P3) are presented and in Figures 5 to 7 those of the membranes with solid materials retained by their microfiltration (P4-P6).

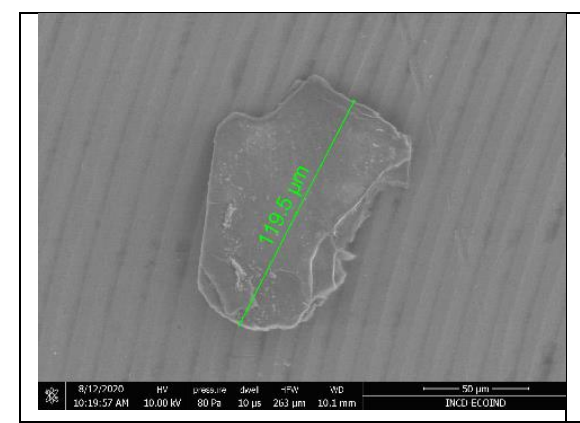

Figure 2a.

P1 Irregular plane microplastics

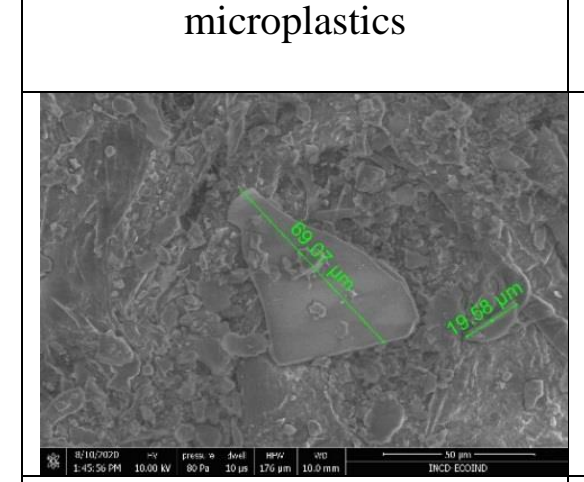

Figure 3a.
P2 Irregular plane

Figure 3a.
P2 Irregular plane microplastics

microplastics

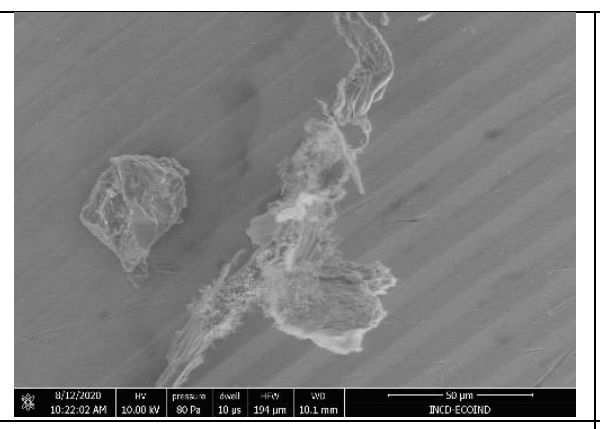

Figure 2b.

P1 Fibers microplastics

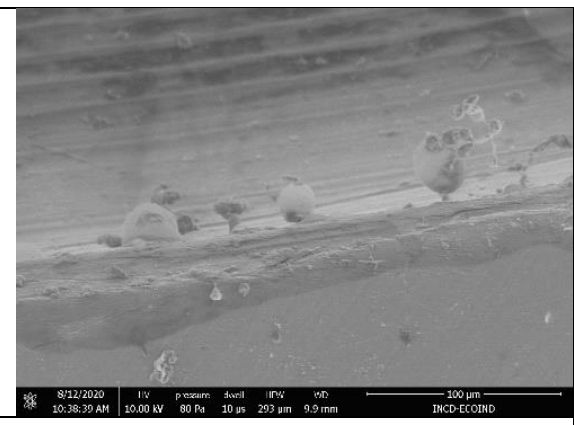

Figure 2c.

P1 Spheres microplastics

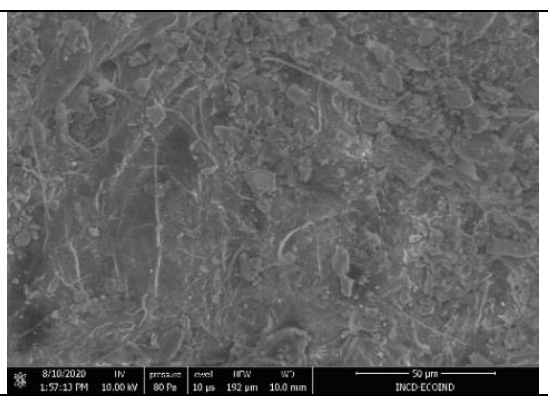

Figure 3b.

P2 Fibers microplastics

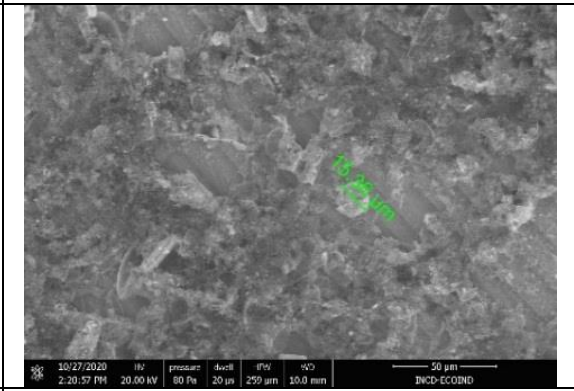

Figure 3c.

P2 Spheres microplastics 

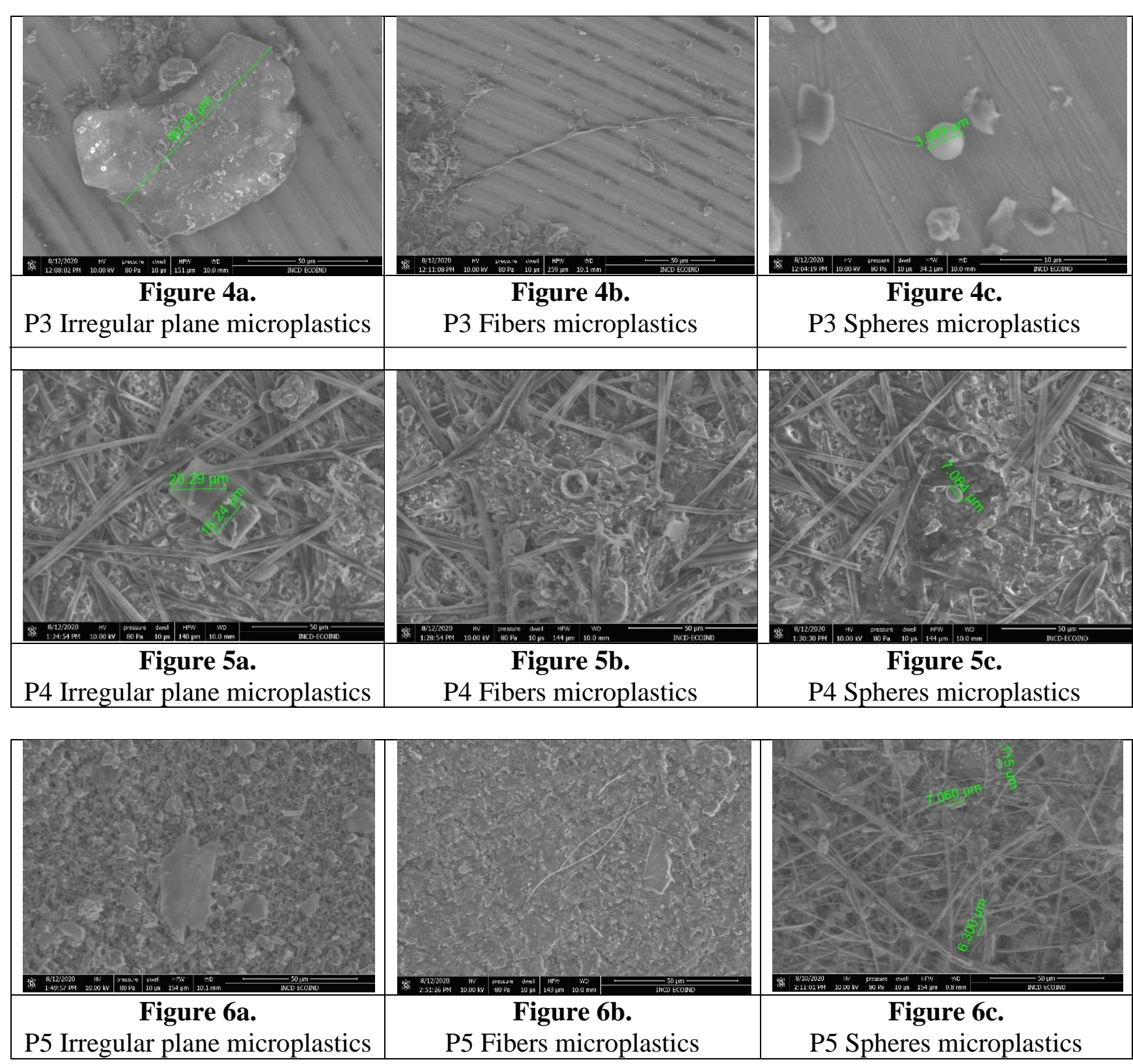

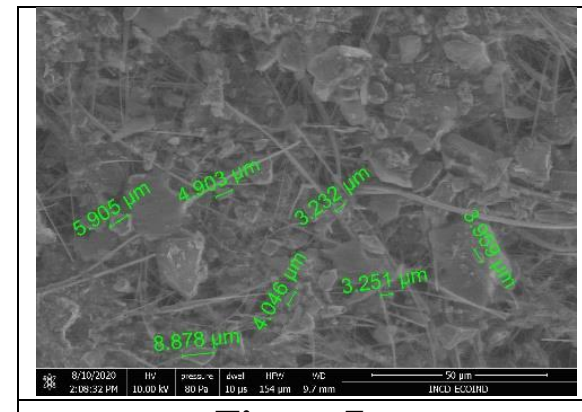

Figure 7a.

P6 Irregular plane microplastics

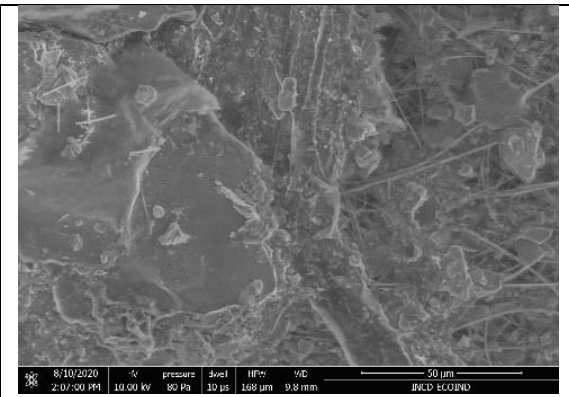

Figure 7b. P6 Fibers microplastics

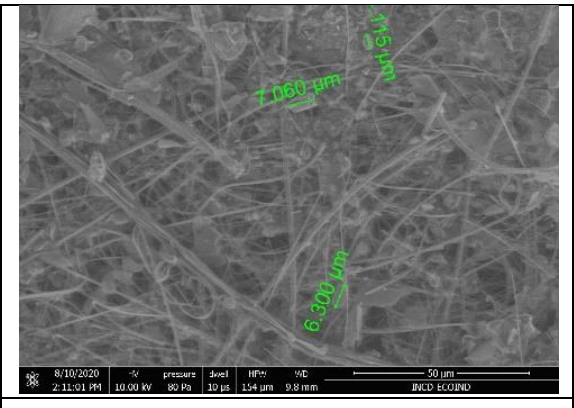

Figure 7c. P6 Spheres microplastics

As it can be seen from the images presented in Figures 2-7, microplastics are found in all the analyzed water samples in the known shapes: irregular planes, fibers and spheres. Their dimensions are variable, ranging between $3.2 \mu \mathrm{m}$ and $119.5 \mu \mathrm{m}$ for irregular plane microplastics and between $3 \mu \mathrm{m}$ and $15 \mu \mathrm{m}$ for spherical microplastics. The dimensions of microplastics in the form of threads are also in the range of tens of microns and cannot be established exactly because in most cases they appear in the form of 
conglomerates. The existing microplastics in the natural receiver of the Jiu River come either from the wastewater discharges prior to the sampling point (upstream, P1) or from the decomposition of packaging thrown into it along the flow route. Downstream from the effluent discharge point of the Targu Jiu treatment plant, the identified microplastics come from the upstream surface water as well as from the treated water. It is found that such microplastics are also found in the treated wastewater, that is not being fully biodegraded in the treatment plant. Quantifying the influence of the content of microplastics in the natural receptor (Jiu River) by the amount of microplastics brought by the wastewater is a complex problem as long as the natural receptor has a content of such contaminants in the upstream. The shape and dimensions of the microplastics retained on the surface of the MF membranes confirm the findings established in the case of the analysis of liquid samples (P1-P3). Logically, the abundance of microplastics on the surface of the MF membranes is much higher than in liquid samples and consequently more difficult to detect in SEM analyzes, especially since microplastics are retained on the filter material and other solid materials. Determining the nature of microplastics (the type of polymer they are made of) cannot be achieved by SEM analysis.

\section{Conclusions}

The characterization by SEM analysis of the water samples taken from the effluent of a treatment plant as well as from its natural receptor (upstream and downstream) highlighted the existence of microplastics in all of them.

The microplastic content of the effluents of the treatment plants leads to the modification of the physical-chemical indicators of the water in their natural receptor. Thus, the content of organic matter and total suspended matter in the downstream water compared to the effluent discharge point is higher than in the water taken and analyzed upstream.

In correlation with the data from the specialized literature, in all the analyzed water samples microplastics with irregular geometry, fibers and spheres were identified. Their dimensions are in the spectrum of micrometers.

The results obtained are in accordance with the known aspects related to the fact that the presence of microplastics in the form of fibers and spheres in the municipal wastewater that enters the treatment plant is the consequence of household activities. The washing of clothes generates the release of textile fibers and the activities of body hygiene generate microplastics in the shape of spheres. Irregular microplastics come from the degradation of plastic waste introduced into municipal wastewater by the packaging thrown uncontrollably in the public space (parks, alleys, streets) entering in the collection system along with precipitations.

The microplastics existence in the effluent of the treatment plant is proof that the treatment technology that includes stages of physical, chemical and biological treatments does not ensure the total removal of pollutants such as microplastics, even if the limits imposed by environmental legislation are respected.

The analysis of microplastics by SEM allows only their highlighting and their geometry, being a first step for the study of the pollution induced by such materials.

Acknowledgments: This work was financially supported by the project "Sistem inovativ de identificare si caracterizare a microplasticelor din apa prin spectrometrie RAMAN", "Innovative system for identification and characterization of microplastics in water by RAMAN spectrometry", Competitiveness Operational Programme 2014-2020, Project Promoting, identifying and implementing partnerships for knowledge transfer in industrial ecology SMIS $2014+105581$, Subsidiary contract no. 13674/30.08.2019.

\section{References}

1.*** Plastics Europe; Plastics-The Facts. An analysis of European Plastics Production, Demand and Waste Data (Plastics Europe, Brussels). 
http://www.plasticseurope.org/application/files/5715/1717/4180/Plastics_the facts_2017_FINAL_for_ website_one_page.pdf. (accesed 29 June 2021)

2. GEYER R., JAMBECK JR., LAW KL, Production, use, and fate of all plastics ever made, Sci Adv., 3 (7), 2017, 1-5, http://doi 10.1126/sciadv.1700782.

3. CIOBANU R., BATRINESCU G., URSAN G.A., CARAMITU A.R., MARINESCU V., BORS A.M., LINGVAY I., Mechanical and Morphostructural Characteristics of Composite Materials Performed by Recycling Mixed Waste of Plastic and Paper, Mater. Plast., 56(3), 2019, 475-478, http://doi.org/10.37358/MP.19.3.5212.

4. PICO Y., BARCELO D., Analysis and Prevention of Microplastics Pollution in Water: Current Perspectives and Future Directions, ACS Omega, 4, 2019, 6709-6719,

http://doi.org/10.1021/acsomega.9b00222.

5. MOHARIR, R.V., KUMAR, S., Challenges associated with plastic waste disposal and allied microbial routes for its effective degradation; A comprehensive review, J. Cleaner Prod., 208, 2019, 65-76, https://doi.org/10.1016/j.jclepro.2018.10.059.

6. DERRAIK J.G.B., The pollution of the marine environment by plastic debris: a review, Marine Pollution Bulletin, 44 (9), 2002, 842-852, https://doi.org/10.1016/S0025-326x(02)00220-5.

7. KIM, L., ARAMA, G.M., CUCIUREANU, A., GUTA, D., Handling specific issues of waste hazardousness evaluation according to waste type, Environmental Engineering and Management Journal, 17 (12), 2018, 2945-2956,

http://www.eemj.icpm.tuiasi.ro/pdfs/vol18/full/no12/12_58_Kim_19.pdf

8. KIM, L., ARAMA, G.M., Ecological risk prediction in relation to the potential detrimental consequences at disposal of different industrial wastes, Environmental Engineering and Management Journal, 17 (9), 2018, 2201-2210,

http://www.eemj.icpm.tuiasi.ro/pdfs/vol17/full/no9/18_188_Kim_17.pdf

9. STANESCU, B., BATRINESCU, G., KIM, L., Establishing interrelations between saturated and unsaturated zone premises for studyng hazards near municipal landfills. Case study, Journal of Environmental Protection and Ecology, 14 (4), 2013, 1608-1613, https://23fc9e25-a-b7e9b206-ssites.googlegroups.com/a/jepe-journal.info/jepe-journal/vol14-no4-2013/1608.pdf

10. KALCIKOVA G., ALIC B., SKALAR T., BUNDSCHUH M., ZGAJNAR-GOTVAJN A., Wastewater treatment plant effluents as source of cosmetic polyethylene microbeads to freshwater, Chemosphere, 188, 2017, 25-31, http://dx.doi.org/10.1016/j.chemosphere.2017.08.131.

11. ZIAJAHROMI, S., NEALE, P.A., RINTOUL, L., LEUSCH, F.D.L., Wastewater treatment plants of a new approach to sample wastewater-based microplastics, Water Research, 112, 2017, 93-99, http://dx.doi.org/10.1016/j.watres.2017.01.042

12. CONLEY, K., CLUM, A., DEEPE, J., LANE, H., BECKINGHAM, B., Watewater treatment plants as a source of microplastics to an urban estuary: Removal efficiencies and loading per capita over one year, Water Research X, 3, 2019, 100030, https://doi.org/10.1016/j.wroa.2019.100030

13. BLAIR, R.M., WALDRON, S., PHOENIX, V.R., GAUCHOTTE-LINDSAY, C., Microscopy and elemental analysis characterization of microplastics in sediment of a freshwater urban river in Scotland, UK, Environmental Science and Polluion Research, 26, 2019, 12491-12504,

https://doi.org/10.1007/s11356-019-04678-1

14. BLAIR, R.M., WALDRON, S., PHOENIX, V.R., GAUCHOTTE-LINDSAY, C., Micro- and nanoplastic pollution of freshwater and wastewater treatment systems, Springer Science Reviews, 5, 2017, 19-30, https://doi.org.10.1007/s40362-017-0044-7

15. BATRINESCU, G., BIRSAN, E., VASILE, G., STANESCU, B., STANESCU, E., PAUN, I., PETRESCU, M., FILOTE, C., Identification of the aquatic ecosystems integrating variables in the Suceava hydrographic basin and their correlations, Journal of Environmental Protection and Ecology, 12 (4), 2011, 1627-1643, http://handle.net/123456789/530 
16. STOICA, C., LUCACIU, I., BATRINESCU, G., STANESCU, B., BIRSAN, E., Evolution an aquatic ecosystem (the Suceava river) for a 3-year period in terms of ecological dynamics, Journal of Environmental Protection and Ecology, 13 (1), 2012, 61-68, http://handle.net/123456789/563

17. MURRAY, A., ORMECI, B., Removal Effectiveness of Nanoplastics (<400 nm) with Separation Processes Used for Water and Wastewater Treatment, Water, 12, 202, 635,

https://doi.org/10.3390/w12030635

$\overline{\text { Manuscript received: } 8.10 .2021}$ 